\title{
In-Service Teachers' Views towards an Environmental Science Education Course Designed around Inquiry Principles
}

\author{
Achilleas Mandrikas \\ University of Athens, Department of Primary Education, Greece \\ Stefanos Asimopoulos \\ University of Thessaly, Department of Primary Education, Greece \\ Constantine Skordoulis \\ University of Athens, Department of Primary Education, Greece
}

Received: Feb. 8, 2015 Accepted: Feb. 27, 2015 Published: February 27, 2015

doi:10.5296/jse.v5i1.7062 URL: http://dx.doi.org/10.5296/jse.v5i1.7062

\begin{abstract}
This paper illustrates a 5-year case study (2007 - 2012) of a course in Environmental Science Education designed for the training of practicing Greek in-service elementary teachers. The aim of the study was to reveal teachers' views towards the course they attended, which was designed on the basis of inquiry principles. This was achieved through an assessment of the course by the 82 participants. The responses of the teachers to 4 open-ended questions were analyzed using content analysis. Results revealed that in-service elementary teachers found the course well-organized and commented favorably for their active participation and group working, the field study, the hands-on experiments and the software used. They would prefer to have more time available for their activities, smaller range of topics and simpler equipment. In general, favorable comments indicate a positive attitude for the course and a successful implementation on behalf of the lecturers while critical comments and suggestions for improvement constitute essential guidelines for the development of similar teacher training courses in the future. Challenges in developing similar courses include the teachers' lack of knowledge in Environmental Science and teachers' need for practical work.
\end{abstract}

Keywords: In-Service Elementary Teachers (IET), Environmental Science Education, In-Service Teacher Training, Inquiry-Based Learning, Content Analysis 


\section{Introduction}

Since the early 1970s, attempts have been made to define Environmental Science (ES), in the light of the need to provide Environmental Education (EE) to future generations. One definition is that ES is "the study of the environment as a whole, including processes (physical, chemical and biological) on and close to the Earth's surface and its direct impact on life" (Qutub, 1973). Another definition considers ES as "a study that unites the contributions of natural and biological sciences under the umbrella of 'ecology'. That requires a systematic study of the environment and the consequences of accelerated human activity" (Morgan, Moran, \& Wiersma, 1973). Lastly, others still maintain that it is "an entirely new cross-disciplinary 'science' that attempts to understand man's impact on the structure and functioning of ecosystems, with the goal of managing complex systems for the benefit and survival of humankind" (Baldwin, Barrett, Gerthel, Fairburn, \& Wilson, 1975). However, since 1977 a view has emerged that considers ES as a new module within Environmental Studies, as it is thought that ES contributes to enriching the scientific knowledge of educators, deepening their understanding of environmental phenomena and allowing them to study the natural and human-made factors that influence them (Barrett \& Puchy, 1977).

It is now suggested that an environmental component should be present in the teaching of Science, so that it is not taught in isolation from considerations of everyday life and the environment (Meichtry, Zint, Carlsen, Hart, Sammel, Zandvliet, \& Dillon, 2001; Dillon \& Scott, 2002). The interaction between EE and ES resulted in the foundation of the field of Environmental Science Education, characterized by the confluence of various sciences, a focus on issues, calculations of scientific views on real systems and an emphasis on local knowledge (Gough, 2002).

Over the last decade, issues of values and policies are being integrated into Science teaching, in an attempt to adapt education to the goal of sustainability (Slay, 2001; Hodson, 2003). This new orientation considers that Science, and also Science Education are social activities, taking place within communities with specific value systems, and that any change to the knowledge base of communities influences its ethics and value base (Carolan, 2006; Lester, Ma, Lee, \& Lambert, 2006; Cotton, 2006; Carter, 2007; Littledyke, 2008). International organizations have adopted the same framework, suggesting action through education on sustainable development (UNECE, 2003; UNESCO, 2005).

\section{Environmental Science and Teacher Training}

Recent years have seen a tremendous rise in provisions for training in-service and pre-service Environmental Science teachers (Comeaux \& Huber, 2001; Gayford, 2002; Veal, Kubasko, \& Fullagar, 2002; Bell, Shepardson, Harbor, Klagges, Burgess, Meyer, \& Leuenberger., 2003; Gough \& Sharpley, 2005; Constible, McWilliams, Soldo, Perry, \& Lee, 2007). In Greece, most teachers working today with environmental topics in primary and secondary education did not have the opportunity to follow the subject during their undergraduate studies (Fikaris, 1998). Environmental Science (ES) and Environmental Education (EE) were gradually introduced into Greek tertiary education at the beginning of the 1990s (Flogaitis, 1998; 
Skordoulis \& Sotirakou, 2005).

At the same time it is generally acknowledged that the more professional knowledge acquired by the teachers, the better their students' achievements (Parkinson, 2009). However, research has shown that teachers of younger children have less of a solid knowledge base in Science and feel uncomfortable teaching Science to their classes (Appleton, 2003; Davis, Petish, \& Smithey, 2006).

The factors with the most negative impact on teachers' attitudes are the lack of scientific background (Osborne, Simon, \& Collins, 2003; Hoban, 2005) and the lack of confidence in their abilities to teach Science (Mulholand \& Wallace, 2005; Nilsson, 2008). In these cases teachers indicate lack of self-confidence and spend less time to teach Science in their school classes (Harlen \& Holroyd, 1997; Palmer, 2001). Even though, they teach in a teacher-centered way, far from inquiry-based learning activities (Jarvis \& Pell, 2006; Abell, 2007). On the other hand, factors that have a positive impact on teachers' attitudes include courses that emphasize practical learning and student-focused interactive learning (Howes, 2002; Cantrell, Young, \& Moore, 2003; Morrell \& Carroll, 2003).

A huge amount of recent research advocates an inquiry based learning approach as the best teaching and learning method for Science generally (McDermott, Shaffer, \& Constantinou, 2000; Anderson, 2002; Dean \& Kuhn, 2006) and Environmental Science in particular (Means, 1998; Bell et al., 2003). Secondary school students taking courses based on research projects improve their scores and particularly their skills in scientific procedures, laboratory skills, diagram skills, interpretation of data and questions asked (Kanari \& Millar, 2004; Hofstein, Navon, Kipnis, \& Mamlok-Naaman, 2005). Students' interest and performance increase further when learning through research activities takes place in a technologically supportive environment (Lee \& Butler, 2003; Lim, 2004; McDonald \& Songer, 2008).

Pre-service teachers receiving training in inquiry based pedagogy to teach Science show a marked improvement in their abilities to plan courses, manage the classroom and involve students in meaningful activities (Marble, 2007). Even in-service elementary teachers, when taught Science with inquiry based principles, develop a more positive attitude to the subject (Van Zee, Hammer, Bell, Roy, \& Peter, 2005; Wee, Shepardson, Fast, \& Harbor, 2007), as well as to the nature of science (NoS) (Schwartz, Lederman, \& Crawford, 2004; Lotter, Harwood, \& Bonner, 2007; Blanchard, Southerland, \& Granger, 2008).

\section{The methodology and design of the Environmental Science Education course}

The Maraslios Teacher Training School was for many years the only in-service training establishment for Greek elementary school teachers. Training lasted 2 years and teachers were required to attend daily classes. Similar institutes were being established in 6 Greek cities under the authority of the University Primary Education Departments. A teacher could attend this form of in-service training just once in his/her career. Unfortunately, Maraslios and all these institutes were discontinued in 2012 for financial reasons, without having yet been replaced by any other form of training.

This paper presents the design and the basic content of the 'Environmental Science 
Education' course taken by in-service elementary teachers at the Maraslios Teacher Training School in the Department of Primary Education at the National and Kapodistrian University of Athens during 5 academic years between 2007 and 2012. Furthermore, the teachers' evaluation concerning the planning and the methodology of the course are presented.

Every activity of the course was designed based on the 'Learning for Use' inquiry based model (Edelson, 2001), which emphasizes 4 distinct teaching criteria: 1 . focus on case studies 2. a balanced inquiry based pedagogical approach 3. use of technology as an essential supporting tool for inquiry based learning 4. evidence-based decision making. Following these 4 criteria, we developed an 11-sessioned course focusing on important environmental problems aiming to improve IET knowledge and to develop their skills through the use of educational tools (Table 1). Every lesson was implemented through a distinct inquiry-based instructional process including 3 sequential stages: 1. motivation (recognition of the need for new knowledge, arousal of curiosity) 2. knowledge construction (creating new knowledge structures through observation and communication, based on a variety of activities) 3 . knowledge refining (organizing and connecting knowledge structures through applications and reflection).

The goal of the activities designed in the 'Environmental Science Education' course was to improve teachers' scientific understanding of contemporary environmental issues and familiarize them with "state of the art" applications of Microcomputer Based Laboratory (MBL) and Information and Communication Technologies Information and Communication Technologies (ICTs) that they could use upon their return in their schools.

There is little doubt that ICTs have introduced significant new learning tools, as well as new aspects of old tools (Avouris \& Page, 1995). In spite of any problems, computer-assisted-learning enables the trainees to expand their search for information to the outside world, to cooperate with colleagues remotely and present information, views and work (Linn, 1998; Cox, 2000). However, there are issues concerning the effects of technology, its improper use, the inequality of access to it, its replacement of the natural world and the environmental impact of its generalized use (Grigoriadou \& Papanikolaou, 2000; Clement, 2002).

ICTs are widely accepted and used for a variety of purposes in Environmental Sciences. The Internet may be used to search for information and educational materials, communicate and express views (Riva, 2001). Therefore, in designing the course, particular focus was given to improving information collection skills and the need to assess websites with environmental content. Educational software with interactive features contributes to a friendlier, more attractive, richer and more multi-faceted presentation of environmental phenomena and enlivens educational processes with creative activities, experiments and investigations (Komis, 2000). Simulations and games are becoming widely accepted as teaching tools for the understanding of environmental phenomena, as they are included in the new recommended teaching strategies in the field of Science. They function as a tool for reconstruction, prediction and explanation (Somekh, 2000).

Research data shows that the main advantages of MBL relate to the use of graphs, as 
designing a graph in real time improves trainees' abilities to detect 'scientific links' concealed within information (Linn, Layman, \& Nachmias, 1987; Mokros \& Tinker, 1987; Dunham \& Osborne, 1991; Ainley, Nardi, \& Pratt, 2000). Other authors have identified other key strengths of MBL, including the focus on discussion, the encouragement of experimentation by adjusting variables and motivating students of different levels (Nachmias \& Linn, 1987). Lastly, there are advantages of a technical nature, such as monitoring an experiment over a period of time and converting qualitative information into quantitative data. This makes MBL an important tool (McDermott, Rosenquist, \& Van Zee, 1987; Browne \& Laws, 2003).

Experiments in the course which we designed were based on the approach suggested by MBL. To conduct the experiments, digital data-collection instruments and sensors were required. Trainees were divided into groups and each group was provided with a computer or data logger, connected to the appropriate sensors. According to the MBL practice, lectures and workshops were combined and emphasis was not placed on memorizing theories or solving traditional science problems, but rather on the development of skills, such as observation, formulation of predictions and provision of justification (Laws \& Pfister, 2002).

Consequently, a basic methodological choice in teaching the course was to avoid traditional lectures and to organize the trainees into groups which performed experiments and/or investigated the relevant topics using their computers.

Groups using computers were made up of 2 trainees, whereas those performing experiments worked in groups of 4 or 5 . The laboratory exercise was based on guided inquiry, with trainees following instructions on work sheets. The methodological steps used for the design of the work sheets were the following: arousing interest, setting out the problem, hypothesis, experiment, observation, interpretation, conclusion, generalization, and application.

Lastly, when teaching the course, care was given in creating a positive emotional atmosphere, by restricting lecturer's intervention, encouraging dialogue in the group and between groups, encouraging groups to present to the class and by organizing a final discussion on possible applications in daily life.

For monitoring purposes, two trainers were used, so as to monitor the work in the groups without giving the impression of being an authority imparting knowledge.

\section{The content of the Environmental Science Education course}

The 'Environmental Science Education' course was an elective course in the 'Mathematics, Science and Technology' stream. The thematic units chosen for the course covered most of the topics presented in the basic textbooks of Environmental Science (Miller, 1996; Skordoulis \& Sotirakou, 2005; Chiras, 2006; Cunningham \& Cunningham, 2008). Alongside lectures, every year a field study was organized either in the mountains or in the sea coast, to train in-service teachers in field work.

The main aims of the course were to improve participants' knowledge base and to develop their skills through the use of educational tools. In Table 1 we present the learning outcomes 
expected for each teaching session in terms of knowledge and skills.

Table 1. Knowledge, skills and teaching tool objectives per lesson

\begin{tabular}{|c|c|c|c|c|}
\hline $\begin{array}{l}\text { Le } \\
\text { sso } \\
\text { n }\end{array}$ & Subject & Knowledge & Skills & Tools \\
\hline 1 & $\begin{array}{l}\text { MBL theory } \\
-\quad \text { digital } \\
\text { measureme } \\
\text { nt } \\
\text { instrument }\end{array}$ & $\begin{array}{l}\text { Function and usefulness of } \\
\text { a datalogger }\end{array}$ & $\begin{array}{l}\text { Practice using } \\
\text { datalogger, } \\
\text { simultaneous } \\
\text { measurement of } 2 \\
\text { variables, recognition } \\
\text { of diagrams }\end{array}$ & datalogger \\
\hline 2 & $\begin{array}{l}\text { ICTs } \\
\text { Environmen } \\
\text { tal website }\end{array}$ & $\begin{array}{l}\text { Internet, criteria for } \\
\text { assessing websites }\end{array}$ & $\begin{array}{l}\text { Inquiry via internet, } \\
\text { thematic research }\end{array}$ & $\begin{array}{l}\text { computer, } \\
\text { websites }\end{array}$ \\
\hline 3 & $\begin{array}{l}\text { Greenhouse } \\
\text { effect }\end{array}$ & $\begin{array}{l}\text { Greenhouse effect, } \\
\text { intensification of } \\
\text { greenhouse effect, global } \\
\text { warming and probable } \\
\text { climate changes }\end{array}$ & $\begin{array}{l}\text { Conducting } \\
\text { experiment, observing } \\
\text { simulations, study of } \\
\text { conceptual charts, } \\
\text { reading tables and } \\
\text { diagrams, } \\
\text { calculations, proposals }\end{array}$ & $\begin{array}{l}\text { datalogger } \\
\text { sensors, } \\
\text { software, } \\
\text { simulations, } \\
\text { conceptual } \\
\text { charts, tables, } \\
\text { diagrams }\end{array}$ \\
\hline 4 & $\begin{array}{l}\text { Ozone layer } \\
\text { depletion }\end{array}$ & $\begin{array}{l}\text { Ozone, structure of the } \\
\text { atmosphere, light } \\
\text { absorption by ozone, } \\
\text { chemical reactions, UV } \\
\text { index, ozone in the } \\
\text { troposphere }\end{array}$ & $\begin{array}{l}\text { Reading chromatic } \\
\text { charts, diagrams, } \\
\text { measurement }\end{array}$ & $\begin{array}{l}\text { Chromatic } \\
\text { charts, } \\
\text { software, } \\
\text { interactive } \\
\text { images, O3 } \\
\text { measurement } \\
\text { stick }\end{array}$ \\
\hline 5 & $\begin{array}{l}\text { Photochemi } \\
\text { cal smog - } \\
\text { temperature } \\
\text { inversion }\end{array}$ & $\begin{array}{l}\text { Photochemical smog and } \\
\text { factors creating it, } \\
\text { temperature inversion }\end{array}$ & $\begin{array}{l}\text { Use of software, } \\
\text { conducting } \\
\text { experiment, } \\
\text { discussion, } \\
\text { formulating } \\
\text { conclusions, reading } \\
\text { diagrams, } \\
\text { development } \\
\text { proposals }\end{array}$ & $\begin{array}{l}\text { Software, } \\
\text { experiment, } \\
\text { modified } \\
\text { diagrams }\end{array}$ \\
\hline 6 & $\begin{array}{l}\text { Meteorolog } \\
\mathrm{y}-\text { wind - } \\
\text { air pollution }\end{array}$ & $\begin{array}{l}\text { Air pollution, pressure, } \\
\text { density, temperature, } \\
\text { movements of air } \\
\text { masses, concentration of } \\
\text { atmospheric pollutants, }\end{array}$ & $\begin{array}{l}\text { Conducting } \\
\text { experiment, reading } \\
\text { diagrams and } \\
\text { meteorological charts, } \\
\text { inquiry via Internet, }\end{array}$ & $\begin{array}{l}\text { Experiment, } \\
\text { software, } \\
\text { angular } \\
\text { diagrams, } \\
\text { meteorologic }\end{array}$ \\
\hline
\end{tabular}




\begin{tabular}{|c|c|c|c|c|}
\hline & & mapping, topography & filling out tables & $\begin{array}{l}\text { al charts, } \\
\text { websites }\end{array}$ \\
\hline 7 & Acid rain & $\begin{array}{l}\text { Acid rain, } \mathrm{pH} \text { scale, } \\
\text { indicator, fuel, acidic } \\
\text { gases, atmospheric } \\
\text { pollutants, effects of acid } \\
\text { rain }\end{array}$ & $\begin{array}{l}\text { Conducting } \\
\text { experiment, use of } \\
\text { software, observation, } \\
\text { conducting } \\
\text { calculations, } \\
\text { completing chemical } \\
\text { reactions, observing } \\
\text { charts }\end{array}$ & $\begin{array}{l}\text { Experiment, } \\
\text { software, } \\
\text { charts }\end{array}$ \\
\hline 8 & $\begin{array}{l}\text { Bioclimatic } \\
\text { architecture }\end{array}$ & $\begin{array}{l}\text { Heat dissemination, } \\
\text { bioclimatic architecture, } \\
\text { thermal balance, energy } \\
\text { saving methods, thermal } \\
\text { conductivity, energy } \\
\text { saving }\end{array}$ & $\begin{array}{l}\text { Conducting } \\
\text { experiment, } \\
\text { discussion, conducting } \\
\text { calculations, } \\
\text { formulating } \\
\text { conclusions, study of } \\
\text { texts }\end{array}$ & $\begin{array}{l}\text { Experiment, } \\
\text { datalogger, } \\
\text { sensors, texts }\end{array}$ \\
\hline 9 & $\begin{array}{l}\text { Renewable } \\
\text { energy }\end{array}$ & $\begin{array}{l}\text { Photovoltaic cells, } \\
\text { hydrogen fuel cells, energy } \\
\text { sources, electricity, } \\
\text { orientation of photovoltaic } \\
\text { cells, electrolysis }\end{array}$ & $\begin{array}{l}\text { Conducting } \\
\text { experiment, reading } \\
\text { graphs, discussion }\end{array}$ & $\begin{array}{l}\text { Experiment, } \\
\text { simulations }\end{array}$ \\
\hline 10 & $\begin{array}{l}\text { Photosynthe } \\
\text { sis }\end{array}$ & $\begin{array}{l}\text { Food chains, } \\
\text { biogeochemical } \\
\begin{array}{l}\text { cycles, } \\
\text { concentration, } \\
\text { oxygen }\end{array}\end{array}$ & $\begin{array}{l}\text { Observation of an } \\
\text { experiment, reading } \\
\text { graphs, discussion }\end{array}$ & $\begin{array}{l}\text { Experiment, } \\
\text { datalogger, } \\
\text { sensors }\end{array}$ \\
\hline 11 & $\begin{array}{l}\text { Chemical } \\
\text { and thermal } \\
\text { water } \\
\text { pollution }\end{array}$ & $\begin{array}{l}\text { hydrological cycle, } \\
\text { biogeochemical cycles, } \\
\text { concentration of ions, } \\
\text { dissolved oxygen content, } \\
\text { eutrophication }\end{array}$ & $\begin{array}{l}\text { Conducting an } \\
\text { experiment, } \\
\text { prediction, creation } \\
\text { and interpretation of } \\
\text { graphs, formulating } \\
\text { conclusions }\end{array}$ & $\begin{array}{l}\text { Experiment, } \\
\text { datalogger, } \\
\text { sensors, } \\
\text { reactors }\end{array}$ \\
\hline
\end{tabular}

The course content was developed over 11 sessions. The first two teaching sessions were introductory and designed to familiarize in-service elementary teachers (IET) with MBL and ICTs. This introductory part provided the necessary knowledge base in IET, since the experimental devices they encountered would be the basic tools used in their experiments and inquiry based activities when investigating specific environmental problems on a global, regional and local scale.

In the first teaching session, IET were introduced to the contemporary systems for collecting, recording and representing data. They practiced in handling and using the digital datalogger, 
focusing on the simultaneous measurement of two variables and reading graphs, a necessary skill for conducting many experiments in Environmental Sciences (Ainley et al., 2000).

In the second teaching session, IET were familiarized with the use of modern computer software and also with investigating and assessing environmental websites. They were introduced to modern software related to geographical information systems, virtual landscapes and virtual reality (Mayer \& Moreno, 2002; Srinivasan, Pérez, Palmer, Brooks, Wilson, \& Fowler, 2006).

In the third teaching session, IET studied the greenhouse effect, along with the intensification of the problem. This is a subject where a great many misunderstandings have been identified among different age groups (Koulaidis \& Christidou, 1999; Papadimitriou, 2004). IET studied the impact of $\mathrm{CO} 2$ on changing temperatures via experiments, using digital dataloggers and sensors. They were then shown how to model the greenhouse effect using several features of a software application: they observed simulations, studied conceptual charts, read tables and diagrams, calculated greenhouse gas emissions and formulated suggestions for ways to reduce greenhouse gases caused by everyday human activities.

The fourth teaching session was dedicated to the topic of ozone depletion, reading chromatic charts and distinguishing between stratospheric and tropospheric ozone, the subject of many misunderstandings (Boyes, Stanisstreet, \& Spiliotopoulou-Papantoniou, 1999; Pekel \& Ozay, 2005). IET followed a work sheet to study a software application, and used integrated interactive images to observe which wavelengths were absorbed by stratospheric ozone, they observed the sequence of chemical reactions that creates CFCs, they investigated why the destruction of ozone over the Antarctic is greater than elsewhere, creating a metaphorical 'hole in the ozone layer' and they observed its changes over time and on an annual basis using chromatic charts and diagrams. They were then introduced to the problem on a local scale, studying the UV ray danger indicator on an annual and daily basis, recommending protection measures. Particular attention was given to the tropospheric ozone, which is a significant photochemical pollutant, and was measured in the lab using special sticks.

In the fifth session, IET studied smog, and the factors that contribute in its creation, using a software application from the internet (http://www.smogcity.com). They studied the factors in current meteorological conditions that contribute in creating smog: temperature, wind speed, degree of sunlight and height of inversion. Lastly, they were asked to generate appropriate solutions to reduce the problem and related dangers. Then, attention was turned to temperature inversion, one of the most significant factors in pollution (Milionis \& Davis, 2002; Hewitt \& Jackson, 2003). IET conducted an experiment simulating the creation of a temperature inversion and they compared modified diagrams using a software application from the internet (http://www.airinfonow.org/html/cocity/coplay.htm) and drew conclusions.

In the sixth session, the problem of local air pollution was studied in relation to meteorological factors and particularly to wind speed and direction (Retalis \& Retalis, 1998; Martilli, Roulet, Junier, Kirchner, Rotach, \& Clappier, 2003). IET simulated an experiment to create wind and discussed basic concepts of Science that are linked to the phenomenon, such as atmospheric pressure, density and heat. Next, they visited the website showing the daily 
report of air pollution levels, provided by the Greek Ministry of Environment (http://www.minenv.gr/1/12/122/12204/g1220400.html). They located specific diagrams representing the concentration of atmospheric pollutants at different measuring stations in the Athens region, based on wind direction. Using table-filling activities and by observing local maps, IET identified how wind direction and topography contribute to the increase in atmospheric pollution (Astitha, Kallos, \& Katsafados, 2008; Retalis, Nastos, \& Retalis, 2009).

In the seventh session, acid rain and its effects on monuments, forests, lakes and soil were studied. First, IET conducted experiments to measure the acidity of different solutions, using $\mathrm{pH}$ test strips, in order to become familiar with the $\mathrm{pH}$ scale. They observed the reaction of acids on pieces of chalk, plaster and marble and recorded changes in the color of a sample by burning sulphur in a closed container with water. Then, they used a specially developed educational software to calculate the concentration of primary atmospheric pollutants, observed the balance conditions in bio-geochemical cycles, studied chemical reactions in order to understand the creation of secondary pollutants, and recorded chemical alterations as a function of time and weather conditions. Lastly, IET observed maps and discussed the effects of acid rain on the forests, on lake and river ecosystems and the erosion of monuments (Mandrikas et al., 2013).

In the eighth session, IET studied heat dispersion and its applications in ecological housing. IET were introduced to the concept of thermal balance and to the basic principle of the upward movement of hot air and its importance in the design of ecological housing. They investigated ways to save energy at home and in the current legislative framework of Greece regarding the energy consumption of buildings. They then experimented on a model house to measure the thermal conductivity coefficient of a variety of materials (glass, wood, plaster), carrying out mathematical calculations and drawing conclusions as to the type of building material that could contribute to energy saving.

In the ninth session, IET studied renewable energy, with particular emphasis on photovoltaics and hydrogen fuel cells. They were introduced to the basic principles of thermodynamics as well as to the problems associated with the use of conventional energy sources, the advantages of renewable energy sources and the current legislative framework in Greece regarding their use. IET conducted experiments to identify the factors contributing to the performance of photovoltaic cells by measuring the electric voltage produced as a function of (i) the distance of the light source from the photovoltaic surface and (ii) the angle of inclination of the light source and the photovoltaic surface. They analyzed and compared data from graphs on voltage-distance and voltage-angle and discussed the optimum orientation of photovoltaic cells in Greece. They then were introduced to the basic principles of operation of hydrogen fuel cells and their application to power a model hydrogen car. They measured the rate at which gases are produced during the electrolysis of water using the fuel cell. They observed that by reversing the procedure a hydrogen car may be propelled and they measured the rate of consumption of gases when a fuel cell is used as an energy source. They discussed the benefits and the problems of hydrogen as a fuel and used simulation software to study the basic principles of operation of renewable energy sources. 
In the tenth session, IET studied photosynthesis as a unique natural process that converts the sun's energy into other forms of energy, thereby creating food chains and biogeochemical cycles. They prepared an experiment including a digital datalogger and a sensor of dissolved oxygen to study the production of oxygen during photosynthesis in an aquatic plant. They predicted, planned, observed, and interpreted graphs showing concentrations of dissolved oxygen over time, under various conditions: absence of $\mathrm{CO} 2$, stirred or not, presence or absence of light, increase or decrease in temperature. They discussed factors that influence the performance of photosynthesis and what distinguishes it from breathing, an area where many misunderstandings exist (Lin \& Hu, 2003; McNall-Krall, Lott, \& Wymer, 2009).

In the eleventh session, IET studied chemical and thermal water pollution and discussed their consequences. During the initial presentation of the topic, the hydrological cycle and the biogeochemical cycles as well as human interventions in the hydrosphere were presented. IET used special measuring kits with reactants to measure concentrations of phosphorus, ammonia, nitric and nitrous ions in different water samples. They also measured the acidity, hardness and dissolved oxygen content of the water. They discussed the consequences of an excessive concentration of ions and eutrophication, as well as the possible consequences of changing water acidity on the aquatic ecosystem. IET then studied the effects of temperature on the concentration of dissolved oxygen with the use of an experimental apparatus. They predicted, planned, observed, and interpreted graphs showing concentrations of dissolved oxygen versus temperature. Lastly, they discussed and drew conclusions on the consequences of increased water temperatures on ecosystems.

\section{Research Method}

\subsection{Objectives}

This work investigates how the in-service elementary teachers (IET) evaluated the structure and the instructional methodology of an Environmental Science Education course at the Maraslios Teacher Training School.

\subsection{Sample}

The sample population consisted of 82 in-service elementary teachers (IET) trained in the Maraslios Teacher Training School in the Department of Primary Education at the National and Kapodistrian University of Athens attending the course 'Environmental Science Education' between 2007 and 2012. Only 27\% (22) of the total sample group was male and $73 \%$ (60) was female. It should be noted that the majority of in-service elementary teachers (IET) in Greece are female. Moreover, none of the IET had attended a similar course during his/her undergraduate studies or during his/her in-service training.

\subsection{Procedure}

A questionnaire consisting of six questions was designed as a research tool. The first question was closed, asking IET to rate their interest in each of the laboratory exercises on a 5 point scale. The other 5 questions were open. In this paper we present and discuss the responses derived from 4 open-ended questions (see Appendix). The questionnaire was filled out 
anonymously by 82 IET. The questionnaires were completed at the end of each semester, after each session but before the final written examination.

\subsection{Analysis}

Questionnaire responses have been analyzed both quantitatively and qualitatively. The responses have been classified by content analysis in categories (Patton, 1987; Eltinge \& Roberts, 1993; Monroe, 2002). In detail, the texts of open-ended answers were analyzed following the principles of classical thematic analysis (Berelson, 1984; Weber, 1990; Neuendorf, 2002). As a unit of analysis we defined "the meaning unit" proposed by Graneheim \& Lundman (2004) and used by Mavrikaki, Antonatou \& Kyridis (2012). This method of analysis enabled us to identify the major trends in our sample. Finally, we selected some characteristic excerpts from the responses in order to support our comments or conclusions.

In order to facilitate the reader in the following description of the results, we want to underline some important facts. First, the total number of responses in each question overcomes $100 \%$, because IET could mention not only one but a number of positive or negative characteristics, of difficulties and of suggestions. Second, we do not measure the results by counting the number of each percentage, but we mention analytically all responses and we evaluate answers as a whole. For example, if a positive characteristic of the course has been mentioned by $40 \%$ of the IET, this should not been translated as a divergence or unpleasantness of the rest $60 \%$. Third, even arithmetically low percentages are important, because they reveal teachers' reflection on the design of the course. Fourth, we would like to emphasize that questions were open-ended, so there was not a list of selected answers to tick, pick, choose, conclude or decide on and IET were free to express their opinion (see Appendix).

\section{Results and discussion}

\section{$6.11^{\text {st }}$ question}

The first question the IETs were asked was, 'What were the positive characteristics of the Environmental Science Education course you attended?' and the results are presented in Table 2 as percentage of references and of IET.

Forty-one per cent $(41 \%)$ of the IET considered that the way in which experiments, measurements and investigations were carried out was a positive element of the course. It would appear that participation in that process provoked strong feelings, increased interest, simulated working methods of scientists and put IETs in their students' shoes:

"Information was combined with ICT, science with the experimental process, and I was happy and satisfied to draw conclusions from the experiments" (IET48)

"The use of experimental apparatus to present and interpret phenomena" (IET22)

“... it put me in the position of the student who tries, with limited knowledge, to manage to formulate hypotheses and design experiments, so I went through what they feel” (IET71) 


\section{Macrothink}

Thirty-three per cent (33\%) considered the use of software and simulations to be important, and an additional 20\% referred to the 'generalized' use of computers and of the internet in particular. The responses show that, as expected, ICT applications contributed to a better understanding of environmental phenomena among IETs and IETs felt they would be useful in their teaching in school:

"The simulations we followed after exercises to arouse interest. It helped us to understand the different phenomena" (IET10)

“The use of ICTs and getting to know interesting websites" (IET37)

"The use of computers in conjunction with observation sheets and discussion" (IET22)

Table 2. Positive points of the Environmental Science Education course

\begin{tabular}{|c|c|c|}
\hline Positive points & Number of responses & Percentage of IET \\
\hline $\begin{array}{l}\text { Experiments, measurements, } \\
\text { investigation }\end{array}$ & 34 & $41 \%$ \\
\hline $\begin{array}{l}\text { Use of software and } \\
\text { simulations }\end{array}$ & 27 & $33 \%$ \\
\hline $\begin{array}{l}\text { Excellent organization and } \\
\text { preparation }\end{array}$ & 25 & $30 \%$ \\
\hline Interesting, relevant subjects & 21 & $26 \%$ \\
\hline $\begin{array}{l}\text { Active participation - } \\
\text { experiential approach }\end{array}$ & 19 & $23 \%$ \\
\hline $\begin{array}{l}\text { Use of computers and } \\
\text { websites }\end{array}$ & 16 & $20 \%$ \\
\hline Very good trainers & 13 & $16 \%$ \\
\hline Workshop format & 11 & $13 \%$ \\
\hline Carrying out field study & 11 & $13 \%$ \\
\hline $\begin{array}{l}\text { Combination of theory and } \\
\text { practice }\end{array}$ & 9 & $11 \%$ \\
\hline $\begin{array}{l}\text { Teaching method using } \\
\text { group work }\end{array}$ & 8 & $10 \%$ \\
\hline $\begin{array}{l}\text { Worksheets / instructions } \\
\text { and guidance }\end{array}$ & 6 & $7 \%$ \\
\hline $\begin{array}{l}\text { Pleasant learning } \\
\text { environment }\end{array}$ & 6 & $7 \%$ \\
\hline $\begin{array}{l}\text { Presentation in different } \\
\text { ways }\end{array}$ & 5 & $6 \%$ \\
\hline Other responses & 19 & \\
\hline Total responses & $230 / 82$ & \\
\hline
\end{tabular}

Thirty per cent $(30 \%)$ of participants considered the organization and preparation of the 
course 'excellent', both on a day-to-day and overall level. The result was an increase in interest, better understanding and a better image of the lecturers:

"There was a noticeably good organization of the content of each lesson, which along with the use of software made the content of the lessons more interesting" (IET76)

"The simple and clear way the subjects were presented contributed to my understanding or clarifying subjects in environmental science that I previously found difficult. This was due in large part to the excellent, methodical and targeted work of the trainers" (IET36)

Twenty-six per cent (26\%) of the IETs found the subjects interesting, relevant and applicable to everyday life. IET particularly mentioned the improvement of their scientific knowledge, something they judged to be useful in their work in school:

"Information about phenomena we hear about day to day without knowing basic facts about them" (IET3)

“Knowledge about subjects that I didn't have scientific knowledge about, including some quite basic points. I can have a view on them if something similar comes up in the classroom. I am sufficiently curious now to look for more information” (IET31)

Twenty-three per cent $(23 \%)$ of IET enjoyed their active involvement in participative exercises within the experiential context and $13 \%$ enjoyed the field study, which they had not done as part of any other teacher training programme:

"The field study, which was interspersed with the course in an integrated and enjoyable way" (IET71)

"The experiential knowledge and coming into contact with nature (mountains, sea), implementing theory and carrying out experimental studies” (IET73)

"Active participation in the lesson, the discussions that preceded and followed it and the positive atmosphere among us" (IET45)

The workshop format of the course (13\%), the combination of theory and practice $(11 \%)$, the group work approach $(10 \%)$, instruction via worksheets $(7 \%)$, the presentation of each topic in different ways $(6 \%)$ and the discussion during sessions were important methodological choices when planning the course. IET noticed these choices and viewed them positively, as shown in their responses:

“The workshop style of lessons” (IET9)

"There was a balance between theory and experiments, which sparked our interest and provided us with tools we can use in school” (IET77)

"Each phenomenon was supported by the relevant theory, the workshop part and the software, so there was no room for misunderstandings" (IET57)

"The presentation of each subject in different ways (theory, presentations with computer, experiments, application, cooperative learning, software)” (IET53) 
"Guidance with detailed instructions at the consolidation stage” (IET6)

"That we worked independently on computers and we just followed the instructions on the worksheet” (IET35)

From these replies we can draw a fairly optimistic conclusion about the course, given that overall 230 positive points were expressed; in other words each teacher expressed an average of 2.8. The above percentages relate to basic elements of content, methodology and the organization of the course and we consider that the whole number and the variety of the responses give an indication of the success and effectiveness of the course.

\subsection{2nd question}

The second question the IETs were asked was, 'What were the negative characteristics of the Environmental Science Education course you attended?' (Table 3). Twenty-two per cent $(22 \%)$ of IETs wrote nothing under this question. Furthermore, many stated that they could find no negative points:

“No negative elements” (IET33)

"I don't think there were any negative points" (IET81)

Thirty per cent $(30 \%)$ of the respondents mentioned time pressure as the biggest negative point of the course. IETs felt that they needed to devote more time to each subject, both in order to complete their investigations and to absorb new concepts:

"Low number of classes per week" (IET9)

“I needed more time to complete work" (IET35)

"The diversity of activities and software required more time” (IET70)

The time available for each teaching session was 2 hours, as set by the Maraslios syllabus and could not be changed. So, given the abstract and complex nature of the new concepts and the handicap of teachers to scientific knowledge, IET rightfully complained for time pressure. This is why some of them suggested that the course should be extended in two semesters, but unfortunately this was impossible due to the strict Maraslios syllabus.

A series of small organizational details were recorded as negative points of the course by a small number of IET. Four per cent (4\%) answered that for some lab exercises there were an insufficient number of experimental instruments:

"I would have liked there to have been more instruments, so that we could share one between two instead of 4 or 5 ” (IET20)

“The fact that there weren't a lot of instruments, so that fewer people could work with each instrument (2 or 3 people)" (IET55)

Furthermore, $4 \%$ encountered technical problems with the functioning of instruments, which led the experiments yielding false data: 
"There were times when technical glitches meant that the experiments didn't work very well" (IET38)

"We sometimes had problems with the computers in the classroom” (IET72)

Concerning the apparently huge amount of "other responses", it includes complaints for early morning start time of sessions, request for no written final exam but a final long essay, for not providing a book instead of lecturers' notes, for not free provision of software, i.e. issues related to administration and not with the lectures and the teaching process as such.

From these responses we may surmise that in generally IETs were happy with the course, as there were less than half as many negative comments as positive ones. Overall 85 negative points were mentioned; in other words each IET expressed an average of 1 . We feel that even these few negative comments confirm the success, effectiveness and lively interest raised by the course, as IETs seemed to want more teaching hours, more time, more instruments and more opportunities to work with them.

Table 3. Negative points of the Environmental Science Education course

\begin{tabular}{|c|c|c|}
\hline Negative points & Number of responses & Percentage of IET \\
\hline $\begin{array}{l}\text { Time pressure - not enough } \\
\text { time available }\end{array}$ & 25 & $30 \%$ \\
\hline Nothing & 18 & $22 \%$ \\
\hline $\begin{array}{l}\text { Wide range of topics - many } \\
\text { topics }\end{array}$ & 9 & $11 \%$ \\
\hline $\begin{array}{l}\text { Experiments, instruments } \\
\text { and scientific knowledge too } \\
\text { difficult for elementary } \\
\text { school }\end{array}$ & 8 & $10 \%$ \\
\hline $\begin{array}{lrr}\text { Large } & \text { volume } & \text { of } \\
\text { information } & \text { and } & \text { new } \\
\text { concepts } & & \end{array}$ & 7 & $9 \%$ \\
\hline $\begin{array}{l}\text { Difficulties with knowledge } \\
\text { of physics and chemistry }\end{array}$ & 6 & $7 \%$ \\
\hline $\begin{array}{l}\text { Technical problems with } \\
\text { experiments }\end{array}$ & 3 & $4 \%$ \\
\hline $\begin{array}{l}\text { Insufficient } \begin{array}{l}\text { number of } \\
\text { instruments for some } \\
\text { exercises }\end{array} \\
\end{array}$ & 3 & $4 \%$ \\
\hline Other responses & 24 & \\
\hline Total & 85 & \\
\hline
\end{tabular}

\subsection{3rd question}

The third question the IETs were asked was, 'What were the difficulties you faced in implementing the experiments and laboratory activities?' (Table 4). The responses given are 
consistent with those given to the previous questions of the questionnaire. Most difficulties seem to have been technical in nature, while $32 \%$ stated that they had difficulties handling the digital datalogger during the first session:

“It was hard to use the digital instrument to begin with” (IET70)

"The difficulties I faced were in the first exercise, when we couldn't coordinate as a team and understand how the instructions wanted us to think and act. Those procedures became automatic over the course of the lessons though" (IET39)

Table 4. Difficulties faced by IET

\begin{tabular}{|l|l|l|}
\hline Issue & Number of IET & Percentage of IET \\
\hline $\begin{array}{l}\text { Gaps in knowledge } \\
\text { (various) }\end{array}$ & 54 & $52 \%$ \\
\hline Using digital instruments & 26 & $32 \%$ \\
\hline $\begin{array}{l}\text { Taking measurements with } \\
\text { datalloger }\end{array}$ & 13 & $16 \%$ \\
\hline No difficulties & 7 & $9 \%$ \\
\hline Other & 3 & $4 \%$ \\
\hline Total & 103 & \\
\hline
\end{tabular}

The main difficulty faced by IETs was a lack of basic knowledge of the environmental issues studied. Overall, $52 \%$ of IET stated that they have never approached the science behind environmental issues, such as ozone depletion, chemical pollution of water, and phenomena such as photosynthesis, temperature inversion, wind and meteorological charts:

"I often had difficulties filling out worksheets, as I didn't know the theory well enough" (IET14)

"I had gaps in my knowledge in all exercises” (IET71)

"I had problems with the hole in the ozone layer, because it involved chemical reactions" (IET5)

"I found everything to do with chemistry difficult" (IET52)

"I had problems with temperature inversion, in terms of the knowledge required...” (IET55)

"I had a hard time understanding temperature inversion because of the new concepts it introduced" (IET60)

"I had gaps in my knowledge and had problems understanding temperature inversion" (IET76)

"I had difficulties with meteorology" (IET10)

"It was hard for me to get used to reading meteorological charts" (IET35)

"I had particular difficulties with photosynthesis” (IET27) 
These types of problems can affect the IETs' self confidence and their participation in the experiments, as shown by previous research (Smith \& Anderson, 1999; Klein, 2001; Gunning $\&$ Mensah, 2011). Some comments are indicative:

"I had difficulties with all the exercises, because of my problems of knowledge of Science. I chose this course because I have problems and gaps" (IET41)

"I had problems with all of them, because it was the first time that I had done experiments" (IET51)

Thirty-two per cent (32\%) of IETs stated that they had problems with the activities designed for them to become familiar with the digital instruments (dataloggers). But it appears that as time passed and experience was gained, these difficulties decreased. However, $16 \%$ stated that they had problems with the instruments and taking measurements generally:

"I had quite a lot of problems with the digital instruments where we were supposed to observe a variation curve and measure time” (IET45)

"I had difficulties with the instruments generally, not because the instructions weren't clear, but because I wasn't familiar with the technology" (IET59)

"The biggest problem for me was using the instruments and reading the data collected, I needed more time to practise that, so that I could better use them" (IET69)

These responses are an insight into the lack of skills the IETs generally have in their interaction with the Science Lab and in reading diagrams in particular (Smith \& Anderson, 1999; Lowe, 2003). Even the clear guidelines could not compensate for a lack of experience in handling instruments, conducting experiments and taking measurements. Only, 9\% of IETs said that they faced no problems with the laboratory exercises.

\subsection{4th question}

The fourth question the IETs were asked was, 'What do you suggest could be done to improve the Environmental Science Education course you attended?' (Table 5). Trainees' answers reveal a positive approach to the course. It is worth noting that $21 \%$ of IET could offer no suggestions for improvement and wanted the course to remain as it is.

"Carry on. It was the most interesting course in the Maraslios Teacher Training School” (IET82)

“Don't change anything. Very interesting course!” (IET43)

Several IET suggested increasing teaching hours in different ways. Eighteen per cent $(18 \%)$ requested an increase in teaching hours through extending the course over two semesters, in order to have enough time to study all the course content:

"It should be divided into two separate courses, in order to give more time to all units" (IET15)

"It should take place over two semesters instead of one" (IET49) 
"The course should be provided over two semesters instead of one, in order to cover the material of Environmental Science Education, plus the experimental lessons where we IET could learn” (IET67)

Fifteen per cent $(15 \%)$ suggested that subjects and experiments should be presented in a way that can have a direct implementation in the primary school class. This is a frequent request from IET for all academy subjects. In the case of the Environmental Science Education course, this was difficult to be satisfied, because processes away from human sensation is impossible to be recorded or ascertained without dataloggers, complex equipment or software simulations. These instructional means notably contribute in IET comprehension, but they are not always appropriate for teaching students. We raised this issue in the first lesson of the course, but some teachers continued to ask for it up to the end.

Eleven per cent (11\%) called for an extension of the field study and time spent outside of the classroom. This guide us to suppose that the IET education until now was more theoretical and had lacked experiential activities, this is why they like outdoor education and practical activities:

"I would like to have done more field studies, more practical activities in the classroom" (IET74)

“More experiential teaching - visits to outdoor places. It was fantastic!" (IET55)

Two well-justified, reasonable suggestions came from $4 \%$ of IET, who called for more instruments or smaller groups:

"I would have preferred us to make up smaller groups" (IET29)

"I suggest providing more materials and instruments" (IET55)

"Perhaps if there was more equipment, particularly for measurements, it would help us to form smaller groups and we could observe the experiments from closer hand" (IET68)

Lastly, some other isolated comments show that the course itself was positive, but made suggestions that fall outside the remit of trainers:

"Trainees should be provided with a CD with all the software presented on it" (IET9)

“The course should be taught in schools” (IET78)

"The course should be taught to all public sector workers" (IET76)

These three requests all show the positive reception of the course and IETs positive reactions to it.

Concerning the "other responses", teachers' suggestions were compatible with previous mentioned negative points, like early start time of sessions, sessions cancelled due to strikes in transport, lack of a book provided, lack of a CD provided etc. We did not further discuss them, because they are issues not concerning the design of the course. Nevertheless, there were some interesting suggestions, like the existence of an initial preparative lesson on 
physics and chemistry, the possibility of IET preparation before each lesson, the IET participation in complex experiments setup, and introduction of current subjects like recycling.

Table 5. Suggestions for improvement for the Environmental Science Education course

\begin{tabular}{|c|c|c|}
\hline Suggestions & Number of responses & Percentage of IET \\
\hline $\begin{array}{l}\text { No suggestions - continue as } \\
\text { at present }\end{array}$ & 17 & $21 \%$ \\
\hline $\begin{array}{l}\text { Increase teaching time or } \\
\text { spread over two semesters }\end{array}$ & 15 & $18 \%$ \\
\hline $\begin{array}{l}\text { Subjects and experiments } \\
\text { presented in a way that is } \\
\text { directly adaptable to } \\
\text { primary school }\end{array}$ & 12 & $15 \%$ \\
\hline $\begin{array}{l}\text { Fewer subjects taught over a } \\
\text { longer period of time }\end{array}$ & 10 & $12 \%$ \\
\hline Increase field study & 9 & $11 \%$ \\
\hline $\begin{array}{l}\text { Final exam in the form of a } \\
\text { project }\end{array}$ & 8 & $10 \%$ \\
\hline Smaller working groups & 3 & $4 \%$ \\
\hline More instruments available & 3 & $4 \%$ \\
\hline Other suggestions & 24 & \\
\hline Total & 101 & \\
\hline
\end{tabular}

\section{Conclusions and Teaching Implications}

We consider IETs responses evaluating the Environmental Science Education course to be positive, vindicating essential choices made regarding planning and methodology. These included the practical nature of the course, the combination of experiments and software, linking theory with practice, working in groups, adopting the key stages of guided inquiry learning, and emphasis on usefulness and applications of scientific knowledge in daily life. These choices are features typical of inquiry learning, a pedagogy that has been put forward with positive results in the field of teaching Environmental Science (Edelson, Gordin, \& Pea, 1999; Brown, 2000; Davis, 2000; Comeaux \& Huber, 2001; Bell et al., 2003; Gough \& Sharpley, 2005).

IETs were largely very positive towards the course and had a positive view of their active engagement in learning activities. However, the fact that they also singled out the usefulness of the experimental approach, the use of computers and working in groups as positive aspects of the course shows that teachers were also influenced positively by the extensive use of "state of the art" applications in the design of the course. The use of Microcomputer Based Laboratory and Information and Communication Technologies facilitated conceptual learning and improved their skills in handling the experimental instruments. This was assisted by the choice of the guided inquiry method using structured work sheets, thus reducing IET 
insecurities and increasing their self-confidence in conducting experiments and research.

The results of our research cannot be generalised, given the limited sample size. Nevertheless, they can underline some guidelines for IET training programs. An effective similar teacher training course on Environmental Science Education should be well-organized and oriented to trainees' active participation, inquiry-based learning and collaborative group working. It should avoid a wide range of topics and give priority to topics with increased local interest. The course should be practical including field study, experiments and software simulations. The "state of the art" applications are useful for recording processes away from human sensation, but IET cannot use them in primary school due to financial cost and students' small age. So, their use should be balanced and clearly addressed to teachers' comprehension. An important challenge of such a training course is the necessity of cover teachers' lack of knowledge in Environmental Science.

We strongly believe that this can be a field of ongoing research that would strengthen the above conclusions. Firstly, research could be conducted into whether the course would be as effective if it were based solely on hands - on experiments, or solely on simulation software (see Harlen \& Doubler, 2004; Delfino \& Persico, 2007; Wright, 2008). Secondly, the effectiveness of the current approach could be compared with a control group using traditional teaching methods (see Lord, 1999; Trundle, Atwood, \& Christopher, 2002; Aivazidis, Lazaridou, \& Hellden, 2006). Lastly, research could be done into how the course affects IET ability to design environmental activities with their students (see Brown, 2000; Bell et al., 2003; Summers, Corney, \& Childs, 2003; Wee et al., 2007) or a comparison could be made with other teachers who had not followed the course (see Marion, Hewson, Tabachnick, \& Blomker, 1999; Plevyak, Bedixen-Noe, Roth, \& Wilke, 2001; Yager, Choi, Yager, \& Akcay, 2009). That would generally require more links between the University and primary and secondary schools and constant communication between university teachers and school teachers. We are in the process of facing this challenge to study the effectiveness of this course along the research axes previously discussed.

\section{References}

Abell, S. (2007). Research on science teachers' knowledge. In S. K. Abell and N. G. Lederman (Eds.), Handbook of research on science education (pp. 1105-1149). Mahwa, New Jersey: Lawrence Erlbaum Associates.

Ainley, J., Nardi, E., \& Pratt, D. (2000). The construction of meanings for trend in active graphing. International Journal of Computers for Mathematical Learning, 5(2), 85-114. http://dx.doi.org/10.1023/A:1009854103737

Aivazidis, C., Lazaridou, M., \& Hellden, G. E. (2006). A Comparison Between a Traditional and an Online Environmental Educational Program. The Journal of Environmental Education, 37(4), 45-54. http://dx.doi.org/10.3200/JOEE.37.4.45-54

Anderson, R. D. (2002). Reforming science teaching: What research says about inquiry. Journal of Science Teacher Education, 13(1), 1-12. http://dx.doi.org/10.1023/a\%3a1015171124982 
Appleton, K. (2003). How Do Beginning Primary School Teachers Cope with Science? Toward an Understanding of Science Teaching Practice. Research in Science Education, 33(1), 1-25. http://dx.doi.org/10.1023/A:1023666618800

Astitha, M., Kallos, G., \& Katsafados, P. (2008). Air pollution modeling in the Mediterranean Region: Analysis and forecasting of episodes. Atmospheric Research, 89(4), 358-364. http://dx.doi.org/10.1016/j.atmosres.2008.03.006

Avouris, N., \& Page, B. (eds) (1995). Environmental informatics. Methodology and applications of environmental information processing. Kluwer Academic Publ.

Baldwin, A. D., Barrett, G. W., Gerthel, C. E. Jr., Fairburn, D. T., \& Wilson, R. E. (1975). A new direction for the training of graduate students in environmental education. The Journal of Environmental Education, 6(3), 50-56. http://dx.doi.org/10.1080/00958964.1975.9941507

Barrett, G.W., \& Puchy, C.A. (1977). Environmental Science: A new direction in Environmental Studies. International Journal of Environmental Studies, 10(2), 157-160. http://dx.doi.org/10.1080/00207237708737309

Bell, C., Shepardson, D., Harbor, J., Klagges, H., Burgess, W., Meyer, J., \& Leuenberger, T. (2003). Enhancing teachers' knowledge and use of inquiry through environmental science education. Journal of Science Teacher Education, 14(1), 49-71. http://dx.doi.org/10.1023/A\%3A1022951523402

Berelson, B. (1984). Content analysis in communication research. New York: Hafner.

Blanchard, M. R., Southerland, S. A., \& Granger, E. M. (2008). No Silver Bullet for Inquiry: Making Sense of Teacher Change Following an Inquiry-Based Research Experience for Teachers. Science Education, 93(2), 322-360. http://dx.doi.org/10.1002/sce.20298

Boyes, E., Stanisstreet, M., \& Spiliotopoulou-Papantoniou, V. (1999). The Ideas of Greek High School Students about the "Ozone Layer". Science Education, 83(6), 724-737. http://dx.doi.org/10.1002/(SICI)1098-237X(199911)83:6<724::AID-SCE5>3.0.CO;2-P

Brown, F. (2000). The Effect of an Inquiry-Oriented Environmental Science Course on Preservice Elementary Teachers' Attitudes about Science. Journal of Elementary Science Education, 12(2), 1-6. http://dx.doi.org/10.1007/BF03173595

Browne, K. P., \& Laws, P. (2003). Exploring the greenhouse effect through physics-oriented activities. Physics Education, 38(2), 115-122. http://dx.doi.org/0031-9120/38/2/302

Cantrell, P., Young, S., \& Moore, A. (2003). Factors affecting science teaching efficacy of pre-service elementary teachers. Journal of Science Teacher Education, 14(3), 177-192. http://dx.doi.org/10.1023/A\%3A1025974417256

Carolan, M.S. (2006). Scientific knowledge and environmental policy: why science needs $\begin{array}{llll}\text { values. } & \text { Environmental } & \text { 229-237. }\end{array}$ http://dx.doi.org/10.1080/15693430601058224

Carter, L. (2007). Sociocultural Influences on Science Education: Innovation for 
$\begin{array}{lllll}\text { Contemporary } & \text { Times. } & \text { Science } & \text { Education, } & \text { 92(1), }\end{array}$ http://dx.doi.org/10.1002/sce. 20228

Chiras, D. D. (2006). Environmental Science. Jones and Bartlett Publishers Inc., 7th ed., Sudburry, MA, USA.

Clement, J. (2002). Model based learning as a key research area for science education. International Journal of Science Education, 22(9), 1041-1053. http://dx.doi.org/10.1080/095006900416901

Comeaux, P., \& Huber, R. (2001). Students as Scientists: Using Interactive Technologies and Collaborative Inquiry in an Environmental Science Project for Teachers and Their Students. Journal of Science Teacher Education, 12(4), 235-252. http://dx.doi.org/10.1023/A\%3A1014226110211

Constible, J.M., McWilliams, R.G., Soldo, E.G., Perry, B.E., \& Lee, R.E. Jr. (2007). An Immersion Professional Development Program in Environmental Science for Inservice Elementary School Teachers. Journal of Geoscience Education, 55(1), 72-79.

Cotton, D. (2006). Teaching controversial environmental issues: neutrality and balance in the reality of the classroom. Educational Research, 48(2), 223-241. http://dx.doi.org/10.1080/00131880600732306

Cox, M. J. (2000). Information and Communications Technologies: their role and value for science Education. In Monk M., Osborne J. (eds) Good Practice in Science Education: What Research has to Say, Buckingham: Open University Press.

Cunningham, W.P., \& Cunningham, M.A. (2008). Environmental Science: A Global Concern, 10th Edition. New York, McGraw-Hill, USA.

Davis, E. A. Petish, D., \& Smithey, J. (2006). Challenges new science teachers face. Review of Educational Research, 76(4), 607-651. http://dx.doi.org/76/4/607

Davis, G. R. (2000). Standards-Based Education and Its Impacts on Environmental Science Education. Electronic Journal of Science Education, 4(3).

Dean, D. Jr., \& Kuhn, D. (2006). Direct Instruction vs. Discovery: The Long View. Science Education, 91(3), 384-397. http://dx.doi.org/10.1002/sce.20194

Delfino, M., \& Persico, D. (2007). Online or face-to-face? Experimenting with different techniques in teacher training. Journal of Computer Assisted Learning, 23(5), 351-365. http://dx.doi.org/10.1111/j.1365-2729.2007.00220

Dillon, J., \& Scott, W. (2002). Editorial - perspectives on environmental education-related research in science education. International Journal of Science Education, 24(11), 1111-1117. http://dx.doi.org/10.1080/09500690210137737

Dunham, P. H. \& Osborne A. (1991). Learning how to see: Students' graphing difficulties. Focus on Learning Problems in Mathematics, 13(4), 35-49. 
Edelson, D.C. (2001). Learning-for-Use: A Framework for the Design of Technology-Supported Inquiry Activities. Journal of Research in Science Teaching, 38(3), 355-385.

http://dx.doi.org/10.1002/1098-2736(200103)38:3\%3C355::AID-TEA1010\%3E3.0.CO;2-M

Edelson, D.C., Gordin, D.N., \& Pea, R.D. (1999). Addressing the Challenges of Inquiry-Based Learning through Technology and Curriculum Design. Journal of the Learning Sciences, 8(3-4), 391-450. http://dx.doi.org/10.1080/10508406.1999.9672075

Eltinge, E., \& Roberts, C. (1993). Linguistic content analysis: A method to measure science inquiry in textbooks. Journal of Research in Science Teaching, 30(1), 65-83. http://dx.doi.org/10.1002/tea.3660300106

Fikaris, I. (1998). Environmental Education in teacher training in Greece. Thessaloniki: Kiriakidis bros. (in Greek)

Flogaitis E. (1998). Environmetal Education. Athens: Ellinika Grammata. (in Greek)

Gayford, C. (2002). Controversial environmental issues: a case study for the professional development of science teachers. International Journal of Science Education, 24(11), 1191-1200. http://dx.doi.org/10.1080/09500690210134866

Gough, A. (2002). Mutualism: a different agenda for environmental and science education. International Journal of Science Education, 24(11), 1201-1215. http://dx.doi.org/10.1080/09500690210136611

Gough, A., \& Sharpley, B. (2005). Toward Effective Teaching and Learning: stories of primary schools' environmental science interest and action. Educational Action Research, 13(2), 191-212. http://dx.doi.org/10.1080/09650790500200284

Graneheim, U.H., \& Lundman, B. (2004). Qualitative content analysis in nursing research: concepts, procedures and measures to achieve trustworthiness. Nurse Education Today, 24(2), 105-112. http://dx.doi.org/10.1016/j.nedt.2003.10.001

Grigoriadou, M., \& Papanikolaou, K. (2000). Learning environments on the Web: The pedagogical role of the educational material. Themes in Education, 1(2), 145-161.

Gunning, A. M., \& Mensah, F. M. (2011). Preservice Elementary Teachers' Development of Self-Efficacy and Confidence to Teach Science: A Case Study. Journal of Science Teacher Education, 22(2), 171-185. http://dx.doi.org/10.1007/s10972-010-9198-8

Harlen, W., \& Doubler, S. J. (2004). Can teachers learn through enquiry on-line? Studying professional development in science delivered on-line and on-campus. International Journal of Science Education, 26(10), 1247-1267. http://dx.doi.org/10.1080/0950069042000177253

Harlen, W., \& Holroyd C. (1997). Primary teachers' understanding of concepts of science: impact on confidence and teaching. International Journal of Science Education, 19(1), 93-105. http://dx.doi.org/10.1080/0950069970190107

Hewitt, C. N. \& Jackson, A. (2003). Handbook of Atmospheric Sciences - Principles and 
Applications. Oxford, Blackwell Publishing, UK.

Hoban, G. F. (2005). Theory-practice links between school and university settings. In Hoban, G. F. (ed), The missing link in teacher education design: developing a multi-linked conceptual framework (pp. 113-115). The Netherlands: Springer.

Hodson, D. (2003). Time for Action: Science Education for an Alternative Future. International Journal of Science Education, 25(6), 645-670. http://dx.doi.org10.1080/09500690305021

Hofstein, A., Navon, O., Kipnis, M., \& Mamlok-Naaman, R. (2005). Developing students' ability to ask more and better questions resulting from inquiry-type chemistry laboratories. Journal of Research in Science Teaching, 42(7), 791-806. http://dx.doi.org10.1002/tea.20072

Howes, V.E. (2002). Learning to teach science for all in the elementary grades: what do pre-service teachers bring? Journal of Research in Science Teaching, 39(9), 845-869. http://dx.doi.org/10.1002/tea.10049

Jarvis, T., \& Pell, A. (2006). The relationship between primary teachers' attitudes and cognition during a two year science in-service programme. In K. Boersma, M. Goedhart, O. De Jong \& H. Eijkelhof. (Eds.), Research and The Quality of Science Education (pp. 157-168). Dordrecht: Springer.

Kanari, Z., \& Millar, R. (2004). Reasoning from data: How students collect and interpret data in science investigations. Journal of Research in Science Teaching, 41(7), 748-769. http://dx.doi.org/10.1002/tea.20020

Klein, B. S. (2001). Guidelines for effective elementary science teacher inservice education. Journal of Elementary Science Education, 13(2), 29-40. http://dx.doi.org/10.1007/BF03176218

Komis, V. (2000). Informatics in Education, University lectures. University of Patras. (in Greek)

Koulaidis, V., \& Christidou, V. (1999). Models of students' thinking concerning the greenhouse effect and teaching implications. Science Education, 83(5), 559-576. http://dx.doi.org/10.1002/(SICI)1098-237X(199909)83:5\%3C559::AID-SCE4\%3E3.0.CO;2$\mathrm{E}$

Laws, P. \& Pfister, H. (2002). Philosophy, Policies \& Procedures. Physics 131/132, Dickinson College.

Lee, H.-S. \& Butler, N. (2003). Making authentic science accessible to students. International Journal of Science Education, 25(8), 923-948. http://dx.doi.org/10.1080/09500690305023

Lester, B.T., Ma, L., Lee, O., \& Lambert, J. (2006). Social Activism in Elementary Science Education: A science, technology, and society approach to teach global warming. International Journal of Science Education, 28(4), 315-339. 
http://dx.doi.org/10.1080/09500690500240100

Lim, B.-R. (2004). Challenges and issues in designing inquiry on the Web. British Journal of Educational Technology, $35(5)$, 627-643. http://dx.doi.org/10.1111/j.0007-1013.2004.00419.x

Lin, C.-Y., \& Hu, R. (2003). Students' understanding of energy flow and matter cycling in the context of the food chain, photosynthesis, and respiration. International Journal of Science Education, 25(12), 1529-1544. http://dx.doi.org/10.1080/0950069032000052045

Linn, M. C. (1998). The Impact of technology on Science Instruction: historical trends and current opportunities. In Fraser B.J, Tobin K.G (eds), International Handbook of Science Education,1, 265-294, Dordrecht: Kluwer Academic Publishers.

Linn, M. C., Layman, J., \& Nachmias, R. (1987). Cognitive consequences of microcomputer-based laboratories: Graphing skills development. Contemporary Educational Psychology, 12(3), 244-253. http://dx.doi.org/10.1016/S0361-476X(87)80029-2

Littledyke, M. (2008). Science education for environmental awareness: approaches to integrating cognitive and affective domains. Environmental Education Research, 14(1), 1-17. http://dx.doi.org/10.1080/13504620701843301

Lord, T. R. (1999). A Comparison between Traditional and Constructivist Teaching in Environmental Science. The Journal of Environmental Education, 30(3), 22-27. http://dx.doi.org/10.1080/00958969909601874

Lotter, C., Harwood, W. S., \& Bonner, J. J. (2007). The influence of core teaching conceptions on teachers' use of inquiry teaching practices. Journal of Research in Science Teaching, 44(9), 1318-1347. http://dx.doi.org/10.1002/tea.20191

Lowe, R.K. (2003). Animation and learning: selective processing of information in dynamic graphics. Learning and Instruction, 13(2), 157-176. http://dx.doi.org/10.1016/S0959-4752(02)00018-X

Mandrikas, A., Parkosidis, I., Psomiadis, P., Stoumpa, A., Chalkidis, A., Mavrikaki, E., \& Skordoulis, C. (2013). Improving Pre-service Elementary Teachers' Education via a Laboratory Course on Air Pollution: One University's Experience. Journal of Science Education and Technology, 22(2), 113-132. http://dx.doi.org/10.1007/s10956-012-9380-1

Marble, S. (2007). Inquiring into Teaching: Lesson Study in Elementary Science Methods. Journal of Science Teacher Education, 18(6), 935-953. http://dx.doi.org/10.1007/s10972-007-9071-6

Marion, R., Hewson, P. W., Tabachnick, B. R., \& Blomker, K.B. (1999). Teaching for Conceptual Change in Elementary and Secondary Science Methods Courses. Science Education, 83(3), 275-307. http://dx.doi.org/10.1002/(SICI)1098-237X(199905)83:3\%3C275::AID-SCE2\%3E3.0.CO;2$\mathrm{C}$ 
Martilli, A., Roulet, Y.-A., Junier, M., Kirchner, F., Rotach, M. W., \& Clappier, A. (2003). On the impact of urban surface exchange parameterisations on air quality simulations: the Athens case. Atmospheric Environment, 37(30), 4217-4231. http://dx.doi.doi.org/10.1016/S1352-2310(03)00564-8

Mavrikaki, E., Antonatou, C., \& Kyridis, A. (2012). Greek Senior High School Students' Perceptions about Science and the Scientific Community as These Appear in the Mass Media. Journal of Studies in Education, 2(4), 32-46. http://dx.doi.org/10.5296/jse.v2i4.2270

Mayer, R.E., \& Moreno, R. (2002). Aids to computer-based multimedia learning. Learning and Instruction, 12(1), 107-119. http://dx.doi.org/09594752/12/1

McDermott, L.C., Rosenquist, M. L., \& Van Zee, E. H. (1987). Student difficulties in connecting graphs and physics: Examples from kinematics. American Journal of Physics, 55(6), 503-513. http://dx.doi.org/55/6/10.1119/1.15104

McDermott, L. C., Shaffer, P. S., \& Constantinou, C. P. (2000). Preparing teachers to teach physics and physical science by inquiry. Physics Education, 35(6), 411-416. http://dx.doi.org/0031-9120/35/6/306

McDonald, S. \& Songer, N. B. (2008). Enacting Classroom Inquiry: Theorizing Teachers' Conceptions of Science Teaching. Science Education, 92, 6, 973-993. http://dx.doi.org/10.1002/sce.20293

McNall-Krall, R., Lott, K. H., \& Wymer, C. L. (2009). Inservice Elementary and Middle School Teachers' Conceptions of Photosynthesis and Respiration. Journal of Science Teacher Education, 20(1), 41-55. http://dx.doi.org/10.1007/s10972-008-9117-4

Means, B. (1998). Melding authentic science, technology, and inquiry-based teaching: Experiences of the GLOBE program. Journal of Science Education and Technology, 7(1), 97-105. http://dx.doi.org/10.1023/A\%3A1022592317752

Meichtry, Y., Zint, M., Carlsen, W., Hart, P., Sammel, A., Zandvliet, D., \& Dillon, J. (eds) (2001). Relations between Science Education and Environmental (Science) Education. Paper presented at the annual meeting of the National Association for Research in Science Teaching. St. Louis, MO, March 27, 2001. Retrieved from http://www.nku.edu/ scienceed/NARST_319.PDF

Milionis, A. E., \& Davies, T. D. (2002). Associations between atmospheric temperature inversions and vertical wind profiles: a preliminary assessment. Meteorological Applications, 9(2), 223-228. http://dx.doi.org/10.1017/S1350482702002074

Miller, G. T. (1996). Living in the environment: Principles, Connections and Solutions, 9th ed. Wadsworth Publishing Company.

Mokros, J., \& Tinker, R. (1987). The impact of MBL on children's ability to interpret graphs. Journal of Research in Science Teaching, 24(4), 369-383. http://dx.doi.org/10.1002/tea.3660240408 
Monroe, M. C. (2002). Evaluation's Friendly Voice: The Structured Open-Ended Interview. Applied Environmental Education and Communication, 1(2), 101-106. http://dx.doi.org/10.1080/15330150213993

Morgan, M. D., Moran, J. M., \& Wiersma, J. H. (1973). An introductory environmental science course for non-science students. The Journal of Environmental Education, 4(3), 39-41. http://dx.doi.org/10.1080/00958964.1973.10801744

Morrell, P.D. \& Carroll, J.B. (2003). An extended examination of pre-service elementary teachers' science teaching self-efficacy. School Science \& Mathematics, 103(5), 246-251. http://dx.doi.org/10.1111/j.1949-8594.2003.tb18205.x

Mulholand, J., \& Wallace, J. (2005). Growing the tree of teacher knowledge. Ten years of learning to teach elementary science. Journal of Research in Science Teaching, 42(7), 767-790. http://dx.doi.org/10.1002/tea.20073

Nachmias, R., \& Linn, M.C. (1987). Evaluations of science laboratory data: The role of computer-presented information. Journal of Research in Science Teaching, 24(5), 491-506. http://dx.doi.org/10.1002/tea.3660240509

Neuendorf, K.A. (2002). The content analysis guidebook. Thousand Oaks, California: Sage Publications, Inc.

Nilsson, P. (2008). Recognizing the needs - Student teachers' learning to teach from teaching. Nordic Studies in Science Education, 4(1), 92-107.

Osborne, J., Simon, S., \& Collins, S. (2003). Attitudes towards science: A review of the literature and its implications. International Journal of Science Education, 25(9), 1049-1079. http://dx.doi.org/10.1080/0950069032000032199

Palmer, D.H. (2001). Factors contributing to exchange amongst preservice elementary teachers. Science Education, 86, 1, 122-138. http://dx.doi.org/10.1002/sce.10007

Papadimitriou, V. (2004). Prospective Primary Teachers' Understanding of Climate Change, Greenhouse Effect, and Ozone Layer Depletion. Journal of Science Education and Technology, 13(2), 299-307. http://dx.doi.org/10.1023/B\%3AJOST.0000031268.72848.6d

Parkinson, P. T. (2009). Field-based preservice teacher research: facilitating reflective professional practice. Teaching and Teacher Education, 25(6), 798-804. http://dx.doi.org/10.1016/j.tate.2008.11.017

Patton, M. Q. (1987). How to use qualitative methods in evaluation. Newbury Park, CA: Sage.

Pekel, F.O., \& Ozay, E. (2005). Turkish High School Students' Perceptions of Ozone Layer Depletion. Applied Environmental Education and Communication, 4(2), 115-123. http://dx.doi.org/10.1080/15330150590934598

Plevyak, L. H., Bedixen-Noe, M., Roth, R. E., \& Wilke, R. (2001). Level of teacher preparation and implementation of environmental education: Mandated and non-mandated 
environmental education teacher preparation states. The Journal of Environmental Education, 32(2), 28-36. http://dx.doi.org/10.1080/00958960109599135

Qutub, M. Y. (1973). Secondary environmental science methods. Columbus, Ohio: Charles E. Merrill Publishing Company.

Retalis, D., \& Retalis, A. (1998). Effects of air pollution and wind on the large-ion concentration in the air above Athens. Journal of Geophysical Research Atmosphere, 103(D-12), 13927-13932. http://dx.doi.org/10.1029/97JD02224

Retalis, A., Nastos, P., \& Retalis, D. (2009). Study of small ions concentration in the air above Athens, Greece. Atmospheric Research, 91, 2-4, 219-228. http://dx.doi.org/10.1016/j.atmosres.2008.05.011

Riva, G. (2001). Communication and interaction in web based learning environments. In Riva G. and Davide F. (eds), Communications Through Virtual Technology: Identity Community and Technology in the Internet Age, IOS Press, Amsterdam, pp. 57-70.

Schwartz, R. S., Lederman, N. G. \& Crawford, B. A. (2004). Developing views of science in an authentic context: An explicit approach to bridging the gap between nature of science and scientific inquiry. Science Education, 88, 4, 610-645. http://dx.doi.org/10.1002/sce.10128

Skordoulis, C., \& Sotirakou, M. (2005). Environment: Science and Education. Athens: Leader Books. (in Greek)

Slay, J. (2001). Research Perspectives on Culturally Sensitive Science Education. Intercultural Education, 12(2), 173-184. http://dx.doi.org/10.1080/14675980120064818

Smith, D. C., \& Anderson, C. W. (1999). Appropriating scientific practices and discourses with future elementary teachers. Journal of Research in Science Teaching, 36(7), 755-776. http://dx.doi.org/10.1002/(SICI)1098-2736(199909)36:7\%3C755::AID-TEA3\%3E3.0.CO;29

Somekh, B. (2000). New technology and leaning: Policy and practice in the UK, 1980-2010. Education and Information Technologies, 5(1), 19-37. http://dx.doi.org/10.1023/A\%3A1009636417727

Srinivasan, S., Pérez, L. C., Palmer, R. D., Brooks, D. W., Wilson, K., \& Fowler, D. (2006). Reality versus Simulation. Journal of Science Education and Technology, 15(2), 137-141. http://dx.doi.org/10.1007/s10956-006-9007-5

Summers, M., Corney, G., \& Childs, A. (2003). Teaching Sustainable Development in Primary Schools: an empirical study of issues for teachers. Environmental Education Research, 9(3), 327-346. http://dx.doi.org/10.1080/13504620303458

Trundle, K. C., Atwood, R. K., \& Christopher, J. E. (2002). Preservice elementary teachers' conceptions of moon phases before and after instruction. Journal of Research in Science Teaching, 39(7), 633-658. http://dx.doi.org/10.1002/tea.10039

UNECE, (2003). Statement on Education for Sustainable Development by the UNECE 


\section{Macrothink}

Ministers of the Environment. Kiev, Ukraine, 21-23 May 2003, ECE/CEP/102/Rev.1

UNESCO, (2005). UN Decade of Education for Sustainable Development 2005-2014, Draft International Implementation Scheme. Paris, ED/2005/PI/H/1.

Van Zee, E. H., Hammer, D., Bell, M., Roy, P., \& Peter, J. (2005). Learning and teaching science as inquiry: A case study of elementary school teachers' investigations of light. Science Education, 89(6), 1007-1042. http://dx.doi.org/10.1002/sce.20084

Veal, W.R., Kubasko, D.S. Jr., \& Fullagar, P. (2002). Web Based Course on Earth and Environmental Science for Preservice and Inservice Teachers. Journal of Science Teacher Education, 13(2), 131-146. http://dx.doi.org/10.1023/A\%3A1015117730569

Weber, R.P. (1990). Basic Content Analysis (2nd ed.). Newbury Park, California: Sage University Paper.

Wee, B., Shepardson, D., Fast, J., \& Harbor, J. (2007). Teaching and Learning About Inquiry: Insights and Challenges in Professional Development. Journal of Science Teacher Education, 18(1), 63-89. http://dx.doi.org/10.1007/s10972-006-9031-6

Wright, G. M. (2008). Web-Based Versus In-Class: An Exploration of No How Instructional Methods Influence Postsecondary Students' Environmental Literacy. The Journal of Environmental Education, 39(2), 33-46. http://dx.doi.org/10.3200/JOEE.39.2.33-46

Yager, R. E., Choi, A., Yager, S. O., \& Akcay, H. (2009). A Comparison of Student Learning in STS vs Those in Directed Inquiry Classes. Electronic Journal of Science Education, 13(2), 186-208. 


\section{APPENDIX}

\section{EVALUATION SHEET OF THE COURSE \\ "ENVIRONMENTAL SCIENCE EDUCATION"}

1. Which of the 11 laboratory lessons was more interesting? Please evaluate each lesson on the scale 1-5 considering 5 as the best.

\begin{tabular}{|l|l|l|l|}
\hline \multicolumn{1}{|c|}{ SUBJECT } & $\begin{array}{c}\text { INTERE } \\
\text { STING }\end{array}$ & \multicolumn{1}{|c|}{ SUBJECT } & $\begin{array}{c}\text { INTERE } \\
\text { STING }\end{array}$ \\
\hline $\begin{array}{l}\text { 1. MBL theory - digital } \\
\text { measurement instrument }\end{array}$ & $\begin{array}{l}\text { 7. Acid rain (experiment } \\
\text { \& software) }\end{array}$ & \\
\hline $\begin{array}{l}\text { 2. ICTs - Environmental } \\
\text { website }\end{array}$ & $\begin{array}{l}\text { 8. Bioclimatic } \\
\text { architecture (experiment) }\end{array}$ & \\
\hline $\begin{array}{l}\text { 3. Greenhouse effect } \\
\text { (experiment \& software) }\end{array}$ & $\begin{array}{l}\text { 9. Renewable energy } \\
\text { (experiment \& software) }\end{array}$ & \\
\hline $\begin{array}{l}\text { 4. Ozone layer depletion } \\
\text { (software) }\end{array}$ & $\begin{array}{l}\text { 10. Photosynthesis } \\
\text { (experiment) }\end{array}$ & $\begin{array}{l}\text { 11. Chemical and } \\
\text { thermal water pollution } \\
\text { (experiment) }\end{array}$ \\
\hline $\begin{array}{l}\text { 5. Photochemical smog - } \\
\text { temperature inversion } \\
\text { (experiment \& software) }\end{array}$ & & & \\
\hline $\begin{array}{l}\text { 6. Meteorology - wind - } \\
\text { air pollution } \\
\text { (experiment \& software) }\end{array}$ & & & \\
\hline
\end{tabular}

2. What were the positive characteristics of the Environmental Science Education course you attended? 


\section{Macrothink

3. What were the negative characteristics of the Environmental Science Education course you attended?

4. What is your opinion about the trainers of the Environmental Science Education course you attended?

5. What were the difficulties you faced in implementing the experiments and laboratory activities?

6. What do you suggest could be done to improve the Environmental Science Education course you attended? 